\title{
A FLAVONOID BIOSIDE FROM THE CELL SAP OF KALANCHOE PINNATA
}

N. P. Maksyutina and M. R. Zub

Khimiya Prirodnykh Soedinenii, Vol. 5, No. 6, p. 597, 1969

UDC 582.977-119:547.972.35

In the sap of Kalanchoe pinnata (airplant kalanchoe) we have detected polysaccharides (about 35-40\%), mineral salts, and flavonoids.

The flavonoid compounds were extracted by chromatography on polyamide after the precipitation of the polysaccharide. Elution with $30 \%$ ethanol in $15 \%$ acetic acid gave a flavonoid with $\mathrm{mp} 197-199^{\circ} \mathrm{C}$ and $\mathrm{R}_{f} 0.61$.

Acid hydrolysis with $1 \% \mathrm{HCl}$ formed quercetin with mp $309-312^{\circ} \mathrm{C}$, and hydrolysis with $1 \%$ formic acid for 5 min yielded desrhamnozhealin [1].

A study of the UV spectra [2] showed the presence of four hydroxyl groups $\left(\mathrm{C}-5, \mathrm{C}-7, \mathrm{C}-3^{\prime}\right.$, and $\left.\mathrm{C}-4^{\prime}\right)$, which proves that the sugar residue is attached at $\mathrm{C}-3$ in the for $\mathrm{m}$ of a bioside.

The glycoside is not cleaved by enzyme preparations of emulsin and snail pancreatic juice.

The properties of the glycoside are close to those of zhealin (quercetin 3-O- $\alpha$-L-arabopyranosyl-2- $\alpha-\mathrm{L}-$ rhamnofuranoside), which is also confirmed by two-dimensional chromatography of mixtures of them in several systems of solvents [1].

REFERENCES

1. N. P. Maksyutina, KhPS [Chemistry of Natural Compounds], 1, 62, 1965.

2. V. I. Litvinenko and N. P. Maksyutina, KhPS [Chemistry of Natural Compounds], 1, 420, 1965.

23 June 1969

Kiev Institute for Advanced Medical Training 